sure of his restrictionist position, with his limitation of science to just "pointer readings".

The application of science to technology marks a fourth opportunity to seek for values, and they are not hard to find. Decisions as to whether and how to apply science inevitably involve valuejudgements, and few would quarrel with that assertion. A point of interest that does emerge from Graham's discussion of medical ethics is that strictly scientific knowledge plays a relatively small part in creating and solving the various dilemmas. The case of amniocentesis is instructive. Medical technology, much more than scientific research, has determined the dimensions of the problem, and the social climate is even more important.

The last kind of way in which science could be said to be value-laden is in its attempted extension and application to social problems as such. In this case it is much more true that science influences values than that it reflects them in its structure and practice. And here, in example after example, Graham demonstrates how readily this happens. He traces the story from Einstein (who, though a prolific writer on social matters, denied that science was directly related to values) to the sociobiologists' conclusion that all values are under genetic control - "the ultimate expansionism". En route he has much to tell of the ways in which science was used to justify ethical norms (as with Social Darwinism and capitalism) or even to explain them. He reminds us that several key figures, as Bohr, changed their views with time; he observes that early eugenics, far from being a tool of the Right was regarded in Weimar Germany as a Leftist deviation; and he cautions us against always supposing that "science is forcing changes in our values"' (p. 267).

The author makes no attempt to conceal his own values. He emerges as a liberal and humane person, determined to see the best in ideologies with which he disagrees. Naturally some of his conclusions are highly contentious. Does it really follow, for instance, that dialectical materialism, whatever its merits, "has been damaged probably beyond the point of salvage - by the fact that it is the political doctrine of an oppressive, nondemocratic state" (p.349)? And is restrictionism always antiscientific? What about Bacon and his two books of Nature and Scripture? And who is he that shall decide the issues of human genetics "without a priori commitments" (p. 255)? Nevertheless we can be grateful for an original, provocative and at times brilliant demonstration of the relevance of historical enquiry to critical issues of our day.

C.A. Russell is Professor of History of Science and Technology at the Open University. His most recent book, Science and Social Change, will be published by Macmillan, London, later this year.

\title{
The second use of nuclear weapons
}

\section{Laurence Martin}

Nuclear Illusion and Reality. By Solly Zuckerman. Pp.154. UK hbk ISBN 0-00-216555-4; US 0-670-51822-0; pbk ISBN 0-00-216554-6. (Collins/Viking: 1982.) Hbk $£ 7.50, \$ 10.95$; pbk $£ 4.95$.

THE illusion which Lord Zuckerman mentions in his title, and which his book is chiefly devoted to exposing, is the idea that nuclear weapons could ever be used as a rational means of defence. A nuclear war would, he asserts, almost certainly become total, mutually annihilating, even if it began in a small way, which is itself improbable:

nuclear weapons may well be classified as strategic, theatre, and tactical, but these terms are meaningless if the use of one of them may mean the use of any.

In effect, then, nuclear weapons only serve to deter the use of nuclear weapons and Lord Zuckerman, while believing in the necessity for such deterrence, advocates what is usually called a "no first use" policy. Unilateral nuclear disarmament would expose the West to nuclear blackmail but, for all practical purposes, defence against aggression short of nuclear attacks must be provided by conventional forces. It is to those, argues Lord Zuckerman, in common with many voices now raised in the Trident debate, that our military energies should be vigorously directed. On the British nuclear force, he is a little ambivalent. He scoffs at the idea that British disarmament would serve as a useful example to others and, while regretting the resources diverted from conventional forces, he concedes the British force is an adequate deterrent to nuclear attacks on the United Kingdom. His most original reason for favouring the maintenance of the British and French forces is, however, that as small but effective deterrents they serve to demonstrate the superfluity of the huge forces maintained by the United States and Soviet Union.

There is clearly a good deal of plausibility in Lord Zuckerman's arguments and they are advanced with admirable lucidity. He pokes some shrewd holes in much that passes for strategic wisdom: pointing out for instance that those who cite the small CEP (Circular Error Probable) of missiles usually fail to consider the 50 per cent of warheads that will fall elsewhere, some with really gross errors; that tactical nuclear weapons have been widely distributed without any convincing doctrine for their use having been concocted even to the present day; that small nuclear warheads are not even very effective for many military purposes and that efforts to use them may consequently entail using large and devastating numbers. Nor can one fault his lengthy explanation of what the effects of large scale nuclear war would be, though we are perhaps not lacking in earlier expositions of this theme.

For those already immersed to some degree in the nuclear debate, however, there are two threads in Lord Zuckerman's book that may be received rather cautiously. One of particular interest to readers of this journal is Lord Zuckerman's repeated attacks on the role - the primary role it often appears - of science and scientists in promoting the "arms race". There is, of course, room for debate as to whether the international military competition that undeniably exists is so unlimited, and so useless, as the metaphor of race suggests. This debate is important, for the answer should influence our readiness to seize on such remedies as are proposed.

So far as the specific role of science is concerned in stimulating the competition, whatever its intensity, there are actually two kinds of scientists in Lord Zuckerman's world. The majority appear to be rather lower grade people, usually called "technicians", who work in military research establishments and foist innovations on the military and the politicians. There is also, however, a small elite of scientific advisers - in Britain including Lord Zuckerman himself, in the United States his friends Jerome Wiesner, Herbert York, Franklin Long and so on who see the uselessness of it all but whose advice never seems to have been taken when anything wrong was done. One can only admire the resolution with which they nevertheless clung on to the job.

The lesser kind of scientist is apparently the fundamental cause of our military predicament: "At base, the momentum of the arms race is undoubtedly fuelled by the technicians in governmental laboratories and in the industries which produce the armaments". There have been several recent studies of this problem, chiefly in the United States, and it undoubtedly deserves even more thought. Neither militarist nor keen disarmer should tolerate military developments that serve no useful strategic purpose. Doubtless some weapons do get made because they are "there" and sometimes, perhaps, a weapon emerges not as the result of a military specification but because a diversified technological process throws up the necessary components: possibly the cruise missile is such a case, coalescing from disparate developments in guidance, propulsion, image suppression and so on.

But this does not mean that the cruise missile is a useless or necessarily deplorable weapon or that its production is the result of spontaneous generation rather than rational strategic decision. Lord Zuckerman seems to regard the MIRV as such a 


\section{New Bioscience} Titles from Pitman

\section{Attention and \\ Schizophrenia \\ Robert D Oades}

What are attention and schizophrenia? How can they be studied? This book reviews evidence as to which brain areas and systems may be involved in these phenomena. The objective is to make pharmacologists, psychiatrists, neurobiologists and behaviourists more aware of each others' problems, and to stimulate an interdisciplinary approach.

February/344 pp/Cased ISBN $0273084909 / £ 22.00$

\section{Molecular Approaches to Evolution \\ Jacques Ninio}

Evolutionary theory is considered in the light of modern advances in molecular biology. The

fundamental aspects of molecular processes, used by the cell in order to evolve, are explained.

February/140 pp/Paper ISBN $0273085212 / £ 5.95$

\section{Neuropharmacology of Insects}

Ciba Foundation Symposium 88

This volume brings together 24 specialists in insect neurobiology, neuropharmacology, genetics and physiology. They present a thorough review of the current state of insect

neuropharmacology, the position it occupies in pharmacology as a whole, and the directions it might profitably take in future.

April/340 pp/Cased

ISBN 027279652 2/£25.00

\section{Competition and}

\section{Coexistence of Species}

\section{A J Pontin}

This much needed book reviews a developing subject for

undergraduate teaching, in which no suitable monograph has previously existed and for which ecology textbooks are too brief and incomplete in coverage.

January/110 pp/Cased ISBN $0273084895 / £ 8.95$

Pitman Books Ltd

128 Long Acre

London WC2E 9AN technology- rather than strategy-led growth. Yet we know that the production of MIRVs was the subject of prolonged, agonized and explicit debate. It is surely going too far to absolve the political leadership of responsibility and assign it all back to the "technicians". It is interesting to note that in its latest Yearbook, the Stockholm International Peace Research Institute flatly repudiates the "driven by technology" thesis and affirms that the political system gets the weapons for which it calls.

Lord Zuckerman does not make very clear what he believes the main danger of the technology-driven arms race to be. Does sheer quantity of weapons make war more likely? There is no definite statement of this. It is not, apparently, that lesser quantities would do much to limit damage, for Lord Zuckerman is adamant that much smaller nuclear forces than the present ones would serve to wreak disaster. But dangerous Lord Zuckerman certainly believes the present military confrontation to be, and he despairs of survival if the East-West competition is not moderated by arms control before the end of the century. Obviously weapons secured for no logical strategic reason would be a waste of money. Reading more between than on the lines, however, it would appear that perhaps the main danger Lord Zuckerman perceives is that an unjustified reliance on nuclear elements in NATO strategy might lead to the use of nuclear weapons despite the fact that it would be irrational to do so.

Not since the first contradictions of the idea of "massive retaliation" has it been possible to deny the reality of this danger, paralleled as it is, in Kennedy's famous phrase "holocaust or humiliation", by the danger of political defeat if the threat to use nuclear weapons proves hollow. Lord Zuckerman's cry for us to look to our conventional forces, and to recognize that nuclear deterrence requires an adequate underpinning of lesser forces, is amply justified.

It is here, however, that an all-too-brief reference to a second debatable theme in the book should be made. Lord Zuckerman is an advocate of "minimal nuclear deterrence", combined with conventional defence, and almost totally rejects any idea that nuclear weapons might be used in limited ways for "warfighting" or to introduce an "intra-war" level of deterrence by nuclear means. His one concession is to admit that

it is just possible that one side might not reply in kind, say to a nuclear 'shot across the bows' or to the attempted 'discriminate' use of nuclear weapons, or even to a first strategic strike.

But he goes on to say that in practice retaliation would be unrestrained for psychological reasons and for lack of technically adequate command and control. When citing with disapproval Dr Harold Brown's statement as Secretary of Defense - as an earlier "scientific adviser" Brown gets good marks - that a flexible strategy should "leave open the possibility of ending an exchange before the worst escalation and damage had occurred, even if avoiding escalation to mutual destruction is not likely', Lord Zuckerman says only "the final ten words of this statement are those that matter".

Whether even "not likely", if accurate - and certainly it is hard to be optimistic about such a juncture - justifies making no provision at all for "controlled" nuclear action in such a contingency is, and is likely to remain, a vexed and probably the most important strategic question of our advancing nuclear age. It is good to have Lord Zuckerman's firm view to ponder. The logic of his position leads to his "no first use" policy. But we should not accept this without first dwelling on two or three difficult questions. What is the effect of a "no first use" policy in a coalition where the main and, if many had their way, the only nuclear forces belong to a distant

\section{IMAGE UNAVAILABLE FOR COPYRIGHT REASONS}

Lord Zuckerman - a view to ponder

ally? If nuclear attack on Western Europe may not be regarded as a "first use" on the United States, should the United States have an identifiable separate level of "retaliation" to deter in such cases? And if a future war in Europe is given a virtually assured "conventional" character, by a "no first use" policy, would the calculation facing a would-be Soviet aggressor - "Can I win a conventional war in Europe" - be dangerously different from the one facing him today - "Can I afford to start a war in which nuclear weapons will probably be used"?

In practice, the balance of deterrence in Europe is probably stable over a wide range of strategic postures, because the stakes are so high and the all-pervasive aura of nuclear fear is so daunting, whatever the explicit strategic doctrines. But in the long run, underlying assumptions about how nuclear deterrence is related to overall deterrence must have profound effects on how states prepare in peacetime and might behave in war. For those who think such questions important, Lord Zuckerman's book offers a provocative and forthright essay well worth the reading.

Laurence Martin, Vice-Chancellor of the University of Newcastle upon Tyne, was Professor of War Studies at the University of London from 1968 to 1977 . He delivered the 1981 BBC Reith Lecture, "Armed Force in the Modern World". 